\title{
Kształcenie umiejętności pisania w edukacji polonistycznej w XXI wieku - od sprawności do kreatywności
}

\section{Developing writing skills in Polish language education in the 21 st century - from efficiency to creativity}

\author{
$\mid$ Jolanta Nocoń
Uniwersytet Opolski
ORCID: 0000-0002-97-1724
}

\begin{abstract}
The article presents a thesis that the increase of the importance of writing skills in the modern world seems necessary to reflect on teaching writing in L1 once again. The concepts of teaching such competence were developed in the 20th century, in a completely different cultural and communication reality and are continued in Polish language education to this day. The considerations presented lead to the identification of problems that should be looked into and issues that should be examined in order to give writing an appropriate educational rank in relation to the cultural and communicative rank and, as a result, take greater responsibility for the learning outcomes achieved. The didactics and practice of teaching writing in L1 require modification, and methodological inspiration can be found in the latest achievements of linguistics, as shown by the example of the use of Maria Wojtak's concept of variants of the genre pattern to counteract the schematicism of texts written by students.
\end{abstract}

Key words: contemporary cultural and communication context, language education, L1 writing skills

Streszczenie: W artykule postawiona została teza, iż ze względu na wzrost rangi umiejętności pisania we współczesnym świecie konieczna wydaje się potrzeba dydaktycznej refleksji nad uczeniem pisania w L1, tym bardziej że koncepcje kształcenia tej kompetencji powstały jeszcze w XX wieku, w zgoła odmiennej rzeczywistości kulturowo-komunikacyjnej, i trwają w edukacji polonistycznej do dziś. Rozważania prowadzą w stronę rozpoznania problemów, z którymi należałoby się zmierzyć i zagadnień, które należałoby rozważyć, by nadać pisaniu adekwatną rangę edukacyjną w stosunku do rangi kulturowo-komunikacyjnej i w rezultacie wziąć większą odpowiedzialności za osiągane efekty kształcenia. Dydaktyka i praktyka uczenia pisania w L1 wymagają modyfikacji, a inspiracji metodycznych można szukać w najnowszym dorobku językoznawstwa, co pokazano na przykładzie wykorzystania koncepcji Marii Wojtak o wariantach wzorca gatunkowego do przeciwdziałania schematyzmowi tekstów redagowanych przez uczniów.

Słowa kluczowe: współczesny kontekst kulturowo-komunikacyjny, kształcenie językowe, umiejętność pisania w L1 
Pisanie jest jedną z tych sprawności/umiejętności/kompetencji, które nabywa się $\mathrm{w}$ procesie edukacji, a nie socjalizacji językowo-komunikacyjnej. Jeszcze do przełomu wieków XX i XXI dominowało przekonanie, że jest to czynność społecznej mniejszości, przydatna głównie dla tych, „którzy piszą, ponieważ ich zawód wymaga od nich tego jako podstawowego elementu ich pracy, i którzy piszą w zgodzie z konwencjami należącymi do ich zwykłego zawodowego toku zajęć" (Davies i Widdowson 1983, 152) i w związku z tym najrzadziej wykorzystywana spośród wszystkich czterech umiejętności komunikacyjnych. Media elektroniczne, współcześnie powszechnie obecne we wszystkich sferach komunikacji społecznej, zmieniły ten trend i nadały pisaniu zdecydowanie wyższą rangę, czyniąc z niej, można chyba zaryzykować takie stwierdzenie, wręcz podstawową kompetencję językowo-komunikacyjną ${ }^{1}$.

Ten swoisty awans kompetencji pisania w konsekwencji zwiększa odpowiedzialność nauczyciela języka ojczystego za efektywność jej nauczania. Stąd też konieczna wydaje się dzisiaj dydaktyczna refleksja nad uczeniem pisania, tym bardziej gdy koncepcje i programy rozwijania tej kompetencji powstały jeszcze w XX wieku, w zgoła odmiennej rzeczywistości kulturowej niż obecnie, i trwają niezmienne w edukacji polonistycznej do dziś. Na nowo należałoby odpowiedzieć na szereg pytań, m.in. o edukacyjną funkcję pisania, o program szkolnej nauki pisania (jej cele, zadania, treści), o skuteczność nauczania-uczenia się pisania (metodykę, organizację, uwarunkowania, nie tylko dydaktyczne, ale i np. socjokulturowe, neuropsychologiczne, tę skuteczność potencjalnie zapewniające), a także o relacje łączące uczenie pisania $\mathrm{z}$ pozostałymi obszarami edukacji polonistycznej oraz zewnętrzną rzeczywistością kulturowo-komunikacyjną. Zasadne byłoby także, i potrzebne, odniesienie się do najnowszego dorobku tych nauk, które mogłyby wpłynąć na efektywność procesu nauki pisania.

Potrzebę refleksji, o której mowa, nie należy łączyć automatycznie z koniecznością stworzenia nowej dydaktyki pisania w języku polskim jako pierwszym (L1), a ewentualnie $\mathrm{z}$ jej modyfikacją. Istotne jest natomiast wzbogacenie świadomości nauczycieli języka polskiego, które pozwoliłoby im spojrzeć na tę kompetencję z odmiennych niż dotąd perspektyw i nowych punktów widzenia, nadać jej adekwatną rangę edukacyjną w stosunku do rangi kulturowo-komunikacyjnej, przemyśleć usytuowanie wobec innych zadań przedmiotowych i w rezultacie wziąć odpowiedzialność za jej kształcenie i osiągane efekty.

W artykule spróbuję spojrzeć na kompetencję pisania w szerokiej, panoramicznej perspektywie lingwodydaktycznej. Skupię się na zaledwie kilku, w moim przekonaniu najważniejszych, zagadnieniach i to tylko sygnalnie, pobieżnie, na znacznym poziomie ogólności. Chcę zarysować szerokie tło, które mogłoby stanowić impuls do refleksji nad uczeniem pisania na

${ }^{1}$ Zofia A. Kłakówna pisze o powstaniu w mediach społecznościowych swoistej agory, na której każdy pisemnie może się wypowiadać $\mathrm{w}$ dowolnych sprawach, na dowolne tematy, w dowolnych formach, także literackich (Kłakówna 2016, 370). 
lekcjach języka polskiego w XXI wieku i tym samym uświadomiłoby, że jest tego potrzeba. W ostatniej części artykułu bardziej szczegółowo odniosę się do jednego z problemów dydaktyki pisania, nienowego, ale ciągle stanowiącego edukacyjne wyzwanie - do tzw. matrycowości/schematyczności tekstu uczniowskiego. Zaprezentuję na tym przykładzie, jak można wykorzystać dorobek językoznawstwa do projektowania metodyki.

Pisanie jest kompetencją niezwykle złożoną, trudną, wymagającą opanowania szeregu sprawności cząstkowych, nie tylko leksykalno-gramatycznych w postaci swoistego kodu językowego właściwego tzw. odmianie standardowej (ogólnej/literackiej) polszczyzny, odmiennego od znanego uczniom z socjalizacji kodu mówionej polszczyzny potocznej, i normatywnych (poprawność zapisu), ale także sensu stricte tekstowych, m.in. lokalnych i globalnych mechanizmów uspójniania linearnej wielozdaniowej struktury w formalną i semantyczną, jednocześnie hierarchicznie uporządkowaną całość zwaną tekstem czy też globalnych wzorców organizacji tej struktury: kompozycyjnych, tematycznych, gatunkowych itp. Ale oprócz tego uczeń musi mieć o czym pisać, co wiąże tę kompetencję z zasobem jego własnej wiedzy o świecie w zakresie pola tematycznego tekstu; musi również posiadać kompetencje poznawczo-mentalne, które warunkują zmierzenie się z problemami formułowanymi w tematach tekstów, takie jak m.in.: analizowanie, abstrahowanie, uzasadnianie, wnioskowanie. Można zatem wnioskować, że każda lekcja języka polskiego wnosi (powinna wnosić $^{2}$ ) choćby pośrednio wkład w trzy obszary kompetencyjne warunkujące jakość tekstu pisanego: rozwija sprawność językową, wzbogaca zakres wiedzy przedmiotowej, usprawnia różne procesy poznawcze. W pewnym sensie pisanie integruje tym samym całość kształcenia polonistycznego, czego świadomość przejawia się w wyrażanym przez wielu nauczycieli polonistów przekonaniu, że najlepszą formą egzaminu maturalnego z języka polskiego byłoby zredagowania przez abiturienta dłuższego tekstu pisemnego. To właśnie w ciągłym, rozbudowanym linearnym tekście pisemnym ujawniają się w sposób rzeczywisty (prawie) wszystkie składowe kompetencje nabywane na lekcjach języka polskiego.

W tym miejscu należałoby postawić pytanie, czy uczeniu pisania (rozwijaniu i doskonaleniu kompetencji tekstotwórczej³, ale także kompetencji

\footnotetext{
${ }^{2}$ Wyrażona $\mathrm{w}$ tym miejscu postulatywność wynika z dominacji na lekcjach języka polskiego metody heurystycznej, co powoduje, że aktywność poznawczą i językowo-komunikacyjną wykazuje na lekcji jedynie pewna grupa uczniów, z reguły tych co najmniej dobrych. Najsłabsi często nie mają okazji do rozwijania swoich kompetencji.

${ }^{3}$ Kompetencja tekstotwórcza stanowi część kompetencji tekstowej, definiowanej jako „zdolność do produkowania i odbierania różnego typu zdarzeń komunikacyjnych”, czyli tekstów (Duszak 1998, 199). W polskiej tradycji lingwodydaktycznej terminami zbieżnymi z kompetencją tekstotwórczą są: sprawność językowa/komunikacyjna, umiejętność/sprawność redagowania wypowiedzi/tekstów. Kompetencja ta należy do podstawowego kulturowego wyposażenia człowieka.
} 
językowej $\left.{ }^{4}\right)$ poświęca się na lekcjach języka polskiego uwagę adekwatną nie tylko do jego edukacyjnej rangi, ale także do potrzeb uczniów? O tyle zasadne, że ujawniany m.in. w mediach społecznościowych rzeczywisty poziom sprawności pisania wzbudza, delikatnie mówiąc, niedosyt i to niezależnie od wieku autora tekstu. I nie chodzi wyłącznie o błędy językowe i ortograficzne, ale o sposób formułowania myśli, prymitywną składnię, ubogi zasób leksyki, przekraczanie norm etycznych komunikacji społecznej, nieznajomość konwencji komunikacyjnych, itd. Niepożądane przeobrażenia w strukturze kompetencji językowo-komunikacyjnej w zakresie pisania mają wymiar znacznie głębszy i poważniejszy - to: analfabetyzm funkcjonalny ${ }^{5}$ i w rezultacie nadawanie odmianie pisanej języka cech hybrydy pisano-mówionej, zakłócenia linearności wywodu myśli skutkujące zanikiem piśmiennego styl myślenia ${ }^{6}$ oraz szerzenie się nowej reguły tekstowości ${ }^{7}$ blokującej myślenie abstrakcyjne na rzecz myślenia konkretnego. Jednym słowem można powiedzieć, że część społeczeństwa potrafi tekst/ wypowiedź zapisać, ale nie napisać.

Za niepożądane zmiany w strukturze kompetencji językowo-komunikacyjnej w zakresie pisania i w konsekwencji niski jej poziom wini się zwykle przeobrażenia kulturowo-społeczne dokonujące się w XXI wieku i mające silny wpływ na socjalizacje językowo-komunikacyjną najmłodszych pokoleń, takie jak m.in. ekspansja potoczności (tzw. nowa oralność), multimedializacja kultury, zwrot ku wizualności, zawłaszczenie sfer komunikacyjnych przez media cyfrowe. Trzeba jednak pamiętać, że każda jednostka ludzka w ciągu swojego życia opanowuje kilka odmian rodzimego języka i używa ich w zależności od uwarunkowań społecznych, sytuacyjnych, pragmatycznych itp. danego aktu komunikacyjnego (zob. Grabias 1994). Proces ten, zwany przełączaniem kodów, staje się problemem edukacyjnym wówczas, gdy uczeń nie potrafi przejść z kodu używanego w sytuacjach pozaszkolnych na obowiązujący na lekcjach języka polskiego kod odmiany ogólnej (literackiej) polszczyzny, a w sytuacjach wymagających zredagowania tekstu pisemnego z kodu odmiany mówionej na kod odmiany pisanej w wersji standardowej języka ${ }^{8}$. Zwykle dlatego, że zbyt słabo opanował te odmiany, w skrajnych przypadkach mogą jawić się mu one wręcz jako języki obce.

Ze względu na rangę umiejętności pisania, o czym była mowa wcześniej, posługiwanie się polszczyzną literacką w wersji pisemnej, a co za tym

${ }^{4}$ Jedna z najważniejszych przyczyn trudności z opanowaniem umiejętności komunikowania się za pomocą pisma to niewystarczający poziom kompetencji leksykalnej i gramatycznej, warunkujący biegłość pisania nie tylko w językach drugich, ale również w języku pierwszym.

5 „Pojęciem tym oznacza się nieumiejętność radzenia sobie w sytuacjach wymagających porozumiewania się za pomocą słowa pisanego, mimo opanowania umiejętności czytania i pisania" (Skudrzyk 2005, 58).

${ }^{6}$ „Opozycja ustności i pisaności dziś nie sprowadza się tylko do różnicy substancji (...), bycie w każdej z tych kultur - kulturze mówienia i kulturze pisma - warunkuje inny styl poznawczy, inny sposób myślenia" (Warchala, Skudrzyk 2010, 93).

7 Ujawnia się w postaci zaburzenia dwóch głównych opozycji różnicujących konstrukcję tworzywa tekstowego: parataktyczność vs. hipotaktyczność składni oraz pole tematyczne vs. linia tematyczna (Warchala, Skudrzyk 2010, 151).

${ }^{8}$ Skala odstępstw będzie oczywiście różna w zależności od poziomu kompetencji konkretnego ucznia. 
idzie poznanie języka na poziomie kodu rozwiniętego (w ujęciu Bernsteina 1990), należy uznać za kluczowe zadanie kształcenia i wychowania językowego w zakresie L1. Jest to odmiana najbardziej uniwersalna, o najszerszym spektrum zastosowań komunikacyjnych, poza tym uwarunkowana normami i konwencjami nie tylko językowo-komunikacyjnymi, ale także estetycznymi i etycznymi, umożliwiająca werbalizację złożonych procesów myślenia i poznania. Oznacza to, że zadaniem szkoły jest nie tylko nauczenie pisania (poprawnego zapisywania wypowiedzi w kodzie graficznym), ale również wyposażenie uczniów w taki poziom kompetencji tekstotwórczej, która gwarantowałaby tworzenie tekstów w regule piśmienności i w odpowiedniej jakości (Kłakówna 2016, 377), zgodnie z przyjętym w dokumentach programowych ideałem/wzorcem tekstu - do tego wątku jeszcze wrócę. Jeśli tak, to konieczne wydaje się skupienie procesu dydaktycznego nie tylko na opanowaniu wzorców gatunkowych, ale także na rzeczywistych potrzebach uczniów w zakresie kompetencji tekstotwórczej, ujawniających się w redagowanych przez nich tekstach.

Takie podejście nie jest jednak oczywiste. O ile na etapie SP w procesie dydaktycznym uwzględnia się, nazwijmy to, językowo-tekstowe składowe pisania (komponenty: językowo-stylistyczny, strukturalny, pragmatyczny powiązane z wzorcem gatunkowym), to już w SPP pisanie staje się narzędziem wykorzystywanym głównie w procesie kształcenia literacko-kulturowego i koncentruje się na komponencie poznawczym (kognitywnym) tekstu uczniowskiego, pozostałe składowe tej kompetencji uznaje się za opanowane i co najwyżej poddaje weryfikacji w procesie oceniania. Pytanie, czy zasadnie?

Odpowiedź nie jest prosta, jako że wszystkie trzy obszary definiujące czynność pisania: język, wiedza i myślenie, są ze sobą powiązane i wzajemnie się warunkują - zatem skupienie się na wiedzy przedmiotowej z zakresu kształcenia literackiego przekłada się niejako automatycznie na rozwijanie zasobu leksykalnego oraz na usprawnienie procesów m.in. analityczno-interpretacyjnych (z zastrzeżeniem zob. przypis 2). Ale to oznacza również, że zgodnie ze znaną glottodydaktyce zasadą, iż tylko suma wszystkich sprawności cząstkowych umożliwia opanowanie języka (w tym przypadku pisania) w całej jego złożoności (Martyniuk 2006, 14), zaniedbanie którejś z nich obniża kompetencję tekstotwórczą jako całość.

W tradycji dydaktyki języka polskiego doskonalenie i rozwijanie kompetencji tekstotwórczej zorientowane jest przede wszystkim na cele i zadania wewnątrzprzedmiotowe i skoncentrowane na pisaniu dla szkoły. Refleksji należałoby natomiast poddać konieczność/potrzebę szerszego niż dotąd otwarcia się szkolnej nauki pisania na zewnętrzne sytuacje i procesy komunikacyjne i to nie tylko jako reakcja na wspomniany już wcześniej destrukcyjny wpływ nowych mediów na strukturę tej sprawności. W wyniku przeobrażeń dokonujących się we współczesnej kulturze komunikacyjnej pojawiają się przecież nieustannie nowe potrzeby komunikacyjne, kształtują 
się nowe dyskursy oraz nowe wzorce i konwencje zachowań językowych, które te potrzeby zaspokajają. Jest to proces naturalny i pozytywny w społecznym wymiarze (Nocoń 2018, 17-26). Otwarcie się szkolnego kształcenia językowego na pisanie dla komunikowania się pozaszkolnego, wzięcie odpowiedzialności, choć w jakiejś części, za komunikacyjno-językową teraźniejszość i przyszłość (także na poziomie szkoły ponadgimnazjalnej, a może właśnie głównie na tym etapie edukacyjnym) zdaje się, że nie powinno podlegać dziś dyskusji. Pytanie, czy ma to być jedynie odtwórcza wiedza o np. niepożądanych zjawiskach w komunikacji w mediach społecznościowych, czy też, co jest znacznie trudniejsze do realizacji w procesie dydaktycznym, kształtowanie postaw wobec nich i pogłębionej świadomości - to drugie wymaga zgoła odmiennej metodyki. Aktualizacji poddać należałoby chyba również zestaw form gatunkowych objętych programem nauczania, tak by uwzględniał on wybrane celowo, a przydatne także w edukacji polonistycznej, nowe współczesne gatunki tekstu.

Na lekcjach języka polskiego poświęca się umiejętności pisania bardzo mało czasu i uwagi, co często tłumaczy się (niebezzasadnie) zbytnim przeładowaniem programu nauczania ${ }^{9}$. W efekcie $\mathrm{w}$ kształceniu polonistycznym doszło do niepokojącego z punktu widzenia efektywności uczenia pisania zaburzenia hierarchii zadań i celów edukacyjnych, w wyniku czego pisanie zyskało niższą rangę niż kształcenie literackie i nauka o języku. Tymczasem sprawność redagowania tekstu pisemnego ze względu na jej złożoność i trudność wymaga wielu systematycznych i celowych ćwiczeń, tym samym czasu; nie tylko przyswajania nowych sprawności tekstotwórczych, ale także rozwijania i doskonalenia już posiadanych ${ }^{10}$ - aby proces przebiegał efektywnie, te trzy etapy muszą zaistnieć z równą uwagę na lekcjach języka polskiego. Jednak między teorią a praktyką edukacyjną istnieje znaczny rozdźwięk, a zaburzenia $\mathrm{w}$ organizacji procesu dydaktycznego mają miejsce w każdym z trzech etapów.

W lingwodydaktyce polskiej opracowane zostały i dobrze opisane liczne teoretyczne koncepcje, modele i strategie kształcenia kompetencji tekstotwórczej. Nauczyciel polonista ma do dyspozycji m.in. pięć metod kształcenia sprawności językowej (Dyduchowa 1988) ${ }^{11}$, metodę doraźnego instruktażu i ćwiczenia redakcyjne „rozwiązujące” i dyscyplinujące język

\footnotetext{
${ }^{9}$ Badania dydaktyki gimnazjalnej w latach 2012-2013 potwierdziły, że uczeniu pisania poświęca się na lekcjach języka polskiego jako L1 zbyt małą uwagę. Szczegóły dostępne w dokumencie wewnętrznym: Dydaktyka literatury i języka polskiego w gimnazjum w świetle nowej podstawy programowe. Region II. Raport końcowy, Sopot/Warszawa 2013. Od tego czasu raczej niewiele się zmieniło, jeśli wziąć pod uwagę jeszcze bardziej przeładowaną treściami kształcenia najnowsza podstawę programową języka polskiego z 2017/2018 roku.

10 Zdaniem Anny Duszak poziom kompetencji tekstowej, w tym tekstotwórczej, „zależy od doświadczenia danego użytkownika z tekstami w ogóle, a z danym typem tekstu w szczególności. W jakimś sensie zależy ona także od treningu, jakiemu użytkownik poddaje się sam lub jest poddawany w celu udoskonalenia sprawności komunikacyjnych w obszarze danego dyskursu" (Duszak 1998, 199).

${ }_{11}$ Metoda analizy i twórczego naśladowania wzoru, metoda norm i instrukcji, metoda przekładu intersemiotycznego, metoda praktyki pisarskiej oraz tzw. ćwiczenia okazjonalne.
} 
(Kłakówna 2016) ${ }^{12}$ oraz koncepcję tekstowych ćwiczeń transformacyjnych (Nocoń 2002) ${ }^{13}$. Na lekcjach przeważa mimo to dysfunkcyjna organizacja procesu. Przebiega on najczęściej następująco: wprowadzenie nowego gatunku poprzez podanie opisujących go gotowych norm i instrukcji, czasami poprzez analizę tekstu wzorcowego; realizacja wzorca gatunkowego w pierwszym tekście ucznia; ocena tego tekstu mająca wymiar diagnozy sumującej i poprawa tekstu przez samego ucznia; czasami pojawiają się nieliczne ćwiczenia wspomagające (głównie leksykalno-frazeologiczne, ewentualnie gramatyczno-stylistyczne) ${ }^{14}$. Kolejne dwa etapy procesu, rozwijanie i doskonalenie kompetencji tekstotwórczej, sprowadzane są wyłącznie do pisania kolejnych tekstów na nowe tematy, ale w znanych już gatunkach, następnie ich oceny i ewentualnie (samo)poprawy. W tak przebiegającym procesie (prawie) w ogóle nie poświęca się czasu komponentom tekstu sprawiającym uczniom problem. Zapomina się ponadto, że warunkiem skutecznego uczenia pisania jest wsparcie procesu dydaktycznego ciągłą diagnozą (tzw. kształtującą). Rozpoznawanie niepowodzeń uczniów, a następnie szukanie rozwiązań metodycznych (o ile dotychczasowe modele okazałyby się niewystarczające lub nieskuteczne), które mogłyby wesprzeć proces kształcenia, to, obok poświęcenia wystarczającego czasu na doskonalenie pisania, konieczność, jeśli myśli się o efektywnym uczeniu pisania.

$\mathrm{Na}$ koniec tej części artykułu zastanowić należałoby się jeszcze nad szkolnym ideałem/wzorcem/modelem tekstu pisemnego, co dla edukacji jest niezwykle istotne, gdyż określa punkt, do którego powinny zmierzać działania podejmowane w procesie dydaktycznym. Ideał ten można wyekscerpować z dwóch dokumentów: podstawy programowej i kryteriów oceny tekstów egzaminacyjnych, ujawnia się też w utrwalonych szkolnych mitach opisujących teksty idealne. To m.in. oczekiwania odnoszące się do: kompozycji, segmentacji i delimitacji (wymaganie trójdzielnej kompozycji z zachowaniem odpowiednich proporcji między częściami, naprzemienności akapitów długich i krótkich); kohezji i spójności lokalnej (obecność spójnościowych wykładników formalnych); stylu (uniwersalny, swoiście „bezstylowy"15); słownictwa (powinno być bogate ${ }^{16}$ ). Tego typu oczekiwania wobec tekstów pisanych w szkole można tłumaczyć dbałością o ich jakość, ale rodzą też zagrożenie, gdy stają się obowiązującą, bezwzględną normą ${ }^{17}$. W realnej komunikacji wcale tak być nie musi, ideały edukacyjne odbiegają

\footnotetext{
${ }^{12}$ Tzw. wprawki - ćwiczenie umiejętności elementarnych, decydujących o dobrej jakości form wypowiedzi, stosowane w razie potrzeby; ćwiczenia analityczne; działania na tekstach i działania poprzez teksty.

${ }^{13}$ Ćwiczenia redakcyjne właściwe, ćwiczenia redakcyjne transformacyjne: adiustacyjne i derywacyjne.

${ }_{14}$ Potwierdzenie można znaleźć w podręcznikach języka polskiego, poradnikach metodycznych oraz dostępnych powszechnie projektach/scenariuszach lekcji. Podobne wnioski wynikły z wywiadów z nauczycielami i uczniami przeprowadzonymi podczas badania dydaktyki gimnazjalnej w latach 2012-2013 (zob. przypis 9).

${ }^{15}$ Zapomina się, że „Nie istnieje jeden wzorzec dobrego stylu. Dobry styl to styl dobrze wywiązujący się z określonej funkcji” (Wierzbicka, Wierzbicki 1970, 24).

${ }_{16} \mathrm{Na}$ ten temat więcej zob. Wiśniewska 2002.

17 Wówczas np. tekst w sposób celowy i funkcjonalny niezachowujący zasady trójdzielnej kompozycji uznany zostanie za tekst z błędem, co skutkować będzie obniżeniem oceny.
} 
w tym przypadku od rzeczywistości. Jednak uelastycznienie wzorca rodzi inny problem, być może istotniejszy z edukacyjnego punktu widzenia ${ }^{18}$ : jak rozpoznać świadome i uzasadnione przekształcenie wzorca gatunkowego przez ucznia (wysoką kompetencję tekstotwórczą) od rozluźnienia norm gatunkowych będących objawem niekompetencji/niskiej kompetencji? ${ }^{19}$ Odnoszenie się za każdym razem do sztywnej matrycy zwalnia nauczyciela od tego typu decyzji.

A przecież ideał tekstu może być różnie opisany, chociażby poprzez odmienne zhierarchizowanie jego komponentów ${ }^{20}$ lub przez sam dobór komponentów, ale przede wszystkim wymaga odpowiedzi na pytanie, kogo chce się wykształcić: odtwórczego autora-rzemieślnika czy kreatywnego autora-twórcę. W pierwszym przypadku oczekuje się od ucznia odtworzenia wszystkich cech wzorca gatunkowego - w rezultacie indywidualne konkretyzacje tekstowe różnią się wprawdzie wykonaniem na poziomie językowo-stylowym i zawartością treściową, ale ich rama gatunkowa jest (prawie) identyczna. W drugim, należałoby tak opisać wzorzec tekstu i tak organizować proces dydaktyczny, by możliwe było wyjście poza tekstowe schematy szczególnie w przypadku uczniów, którzy mają do tego predyspozycje i wystarczające kompetencje.

Teza Michaiła Bachtina o przypisaniu każdemu tekstowi kwalifikacji gatunkowej21 (słynne „mówimy gatunkami”) pozwoliła zdefiniować wzorzec gatunkowy jako abstrakcyjny model pewnego typu tekstów (identyfikowanych nazwą gatunkową), który następnie jest realizowany w konkretnych tekstach. Ta teoria lingwistyczna jest niezwykle wygodna dla edukacji, gdyż uczenie pisania zawsze jest powiązane z uczeniem nadawania testowi określonej ramy gatunkowej. Pytanie, czy opanowanie wzorca gatunkowego jest celem samym w sobie, czy ma służyć innym celom jako narzędzie, którym uczeń swobodnie się posługuje? Czy jest punktem końcowym procesu uczenia (się), czy to raczej powinien być etap pierwszy?

W genologii lingwistycznej do modelowania gatunku ujmowanego jako zespół cech kategorialnych podchodzi się dwojako: 1. gatunkowi jako klasie tekstów przysługuje ściśle określony, zamknięty w ostrych granicach rejestr cech; 2. gatunek to kategoria nieostra, rozmyta, którą „buduje sieć parametrów wzajemnie się warunkujących, obejmujących plan kognitywny, funkcjonalny, sytuacyjno-interakcyjny, strukturalny, aksjologiczny

18 Uelastycznienie wzorca tekstu jest trudne przede wszystkim w sytuacjach egzaminacyjnych - sztywność wymagań gwarantuje porównywalność oceny wówczas, gdy egzaminatorów jest wielu, a rozluźnienie oczekiwań wzmacnia wpływ na ocenę subiektywnego osądu konkretnego egzaminatora.

19 To pytanie w jakiejś mierze retoryczne, gdyż nauczyciel raczej zna swoich uczniów i wie, jakie są ich możliwości tekstotwórcze. Problem nabiera znaczenia w sytuacjach egzaminacyjnych.

${ }^{20}$ Dowartościowane mogą być różne komponenty tekstu, np. bogactwo treści, poprawność zapisu, stosowność języka, styl językowy - w zależności od rangi przypisuje się wybranym kryteriom odpowiednio większą liczbę m.in. punktów (zwiększa ich udział procentowy w skali globalnej oceny).

${ }^{21}$ Również współczesna tekstologia uznaje kwalifikację genologiczną za konieczną i niezbywalną cechę tekstu (więcej Witosz 2005, 108). 
oraz intertekstualny" (Witosz 2005, 109). W dydaktyce pisania opisy wzorców gatunkowych tekstów szkolnych dokonywane są zgodnie z podejściem pierwszym - w poradnikach metodycznych, podręcznikach szkolnych, kryteriach oceny tekstów pisemnych kodyfikacja wzorców gatunkowych obejmuje nawet gatunki uzualne, niemające znormatywizowanych modeli w komunikacji społecznej.

Szukanie egzemplarza idealnego opisanego za pomocą zespołu cech wzorcowych jest ze względu na kontekst edukacyjny niezbędne, o czym była wcześniej mowa. Problem pojawia się wówczas, gdy wzorzec gatunkowy postrzegany zaczyna być jako matryca do pamięciowego zapamiętania i wiernego odtworzenia w każdej jednostkowej tekstowej konkretyzacji, w rezultacie czego uczniowie „zatracają własną indywidualność i konstruują teksty według planów-schematów" a formuliczności wypowiadania się towarzyszy stereotypowość myślenia (Karwatowska, Wiśniewska 1998, 260-261).

Temat maksymalnego skodyfikowania wzorców gatunkowych szkolnych tekstów pisemnych podejmowany jest w lingwodydaktyce polskiej od drugiej połowy XX wieku i do dzisiaj tak naprawdę nie znalazł metodycznego rozwiązania, choć już wówczas zaproponowano działania dydaktyczne mające zapobiegać schematyczności tekstów uczniowskich. Zwrócono m.in. uwagę na konieczność dwuetapowości pracy nad każdym gatunkiem: 1. wprowadzenie schematu i 2. wytrącenie ze schematu (Wiśniewska 2016, 286-289). Nasuwają się pytania: co to jest „wytrącony schemat” i jak wytrącić wzorzec gatunkowy ze schematu? Na drugie z nich odpowiada Wiśniewska, proponując wpisanie tematu tekstu w sytuację komunikacyjną, do której należy dobrać odpowiednie środki językowo-stylistyczne (trawestacje tego samego tematu na różne style), oraz łączenie dwóch wzorców gatunkowych w jednym temacie (Wiśniewska 2016, 286-289). Natomiast model testu wytrąconego ze schematu gatunkowego jak dotąd w polskiej lingwodydaktyce nie został opisany, co oznacza, że kategoryzowany jest intuicyjnie.

Dydaktyka nie funkcjonuje $\mathrm{w}$ naukowej próżni, ma swoje zaplecze naukowe, które może być źródłem inspiracji dla nowych rozwiązań metodycznych, szczególnie wówczas, gdy dotychczasowe modele dydaktyczne okazują się mało efektywne. Dla lingwodydaktyki zorientowanej na kształcenie kompetencji tekstotwórczej to lingwistyka tekstu i inne subdyscypliny, które skupiają się na badaniu tekstów. Takim modelem lingwistycznym, który mógłby wspomóc metodykę pisania w opracowaniu sposobów wytrącania tekstu uczniowskiego ze schematu, ale także pozwoliłby zdefiniować z perspektywy lingwodydaktycznej tekst wytrącony ze schematu jako różne warianty wzorca gatunkowego, jest koncepcja Marii Wojtak $(2004)^{22}$, która opiera się na założeniu, iż „Dynamika procesów komunikacyjnych, zmienność społecznych i kulturowych uwarunkowań - to czynniki,

${ }^{22} \mathrm{O}$ wykorzystaniu koncepcji wariantywności wzorców gatunkowych pisałam już w artykule opublikowanym w czeskim czasopiśmie „Didaktické Studie” (Nocoń 2020). Zagadnienie wydaje mi się niezwykle ważne, stąd chciałabym je przybliżyć polskiemu czytelnikowi. 
które sprawiają, że wzorzec gatunkowy zyskuje kilka wariantów" (Wojtak 2004, 18). Wojtak wyróżnia trzy warianty: 1. wzorzec kanoniczny - obejmuje najbardziej trwałe wyznaczniki gatunkowe (strukturalne, pragmatyczne, stylistyczne, kognitywne); 2. wzorce alternacyjne - powstają w wyniku przekształcenia poszczególnych składników wzorca kanonicznego poprzez redukcje składnika, wymianę komponentu, dodanie nowego składnika: „Wzorce alternacyjne rozluźniają okowy konwencji, stając się przyczyną powstawania gatunkowych form poruszonych, które w trakcie kolejnych ewolucyjnych zmian mogą się wykrystalizować w odmiany gatunkowe" (Wojtak 2004, 18); 3. wzorce adaptacyjne - nawiązują do obcych schematów gatunkowych, mają charakter kolaży gatunkowych. Adaptacje mogą być trwałe (w postaci odmian gatunkowych) lub doraźne (jako niepowtarzalne aktualizacje tekstowe danego gatunku), cząstkowe lub globalne: „W takim przypadku sygnałem przynależności gatunkowej tekstu staje się jego zastosowanie (kontekst życiowy)" (Wojtak 2004, 19). Jeśli odnieść tę koncepcję do poruszonego $\mathrm{w}$ tej części artykułu zagadnienia, to schematyzm gatunkowy należałoby połączyć z realizacjami ograniczającymi się do odtwarzania wzorca kanonicznego, a teksty „wytrącone ze schematu” zinterpretować jako realizacje $\mathrm{z}$ alternacjami lub adaptacjami.

Zgodnie z zasadami stopniowania trudności i przechodzenia od modelu do wariantów modelu proces dydaktyczny powinien przebiegać od wzorca kanonicznego poprzez alternacyjne do adaptacyjnych, wymagających najwyższych kompetencji od ucznia. Zasadne wydaje się także przyporządkowanie momentu wprowadzania kolejnych odmian wzorców gatunkowych do etapów pracy nad daną formą wypowiedzi: etap wprowadzania nowej formy wypowiedzi powinien skupiać się na wzorcu kanonicznym, doskonalenie sprawności realizacji danej formy na poprawianiu zaobserwowanych błędów w realizacjach wzorca kanonicznego oraz wprowadzaniu alternacji gatunkowych, natomiast doskonalenie nabytych kompetencji na różnicowaniu alternacji w obrębie gatunku oraz na realizacjach $\mathrm{z}$ adaptacjami zapożyczonymi z innych gatunków. Dla przykładu, jeśli chodzi o zaproszenia, możliwe alternacje to m.in.: dodanie elementów perswazyjnych (komponent pragmatyczny), dodanie programu (komponent strukturalny), zastosowanie specyficznej odmiany językowej, np. slangu młodzieżowego (komponent stylistyczny); opuszczenie niektórych informacji ze względu na kontekst i sytuację, np. umieszczenie tekstu w mediach społecznościowych (komponent strukturalny), natomiast adaptacje to np. kontaminacje $\mathrm{z}$ reklamą, ogłoszeniem ${ }^{23}$.

Przechodzenie od wzorca kanonicznego do wzorców alternacyjnych i adaptacyjnych wymaga spełnienia dwóch warunków: 1 . tematy tekstów muszą być konstruowane w taki sposób, by umożliwiały alternacje i/lub adaptacje gatunkowe, a nie wyłącznie realizacje kanoniczne; 2 . konieczne jest uelastycznienie kryteriów oceny, tak by nie faworyzowały wzorca

${ }^{23} \mathrm{Na}$ ten temat zob. Nocoń 2018a. 
kanonicznego, a dały się dostosować każdorazowo do specyfiki zadania dydaktycznego i otwieranych przez nie możliwości realizacyjnych, a nie do schematu. Zastrzec przy tym trzeba, iż wszyscy uczniowie powinni opanować wzorzec kanoniczny, pozostałe są fakultatywne. Należy raczej otwierać możliwości do alternacji i adaptacji gatunkowych, a nie zmuszać do nich, pamiętając jednak, że tego typu działania są konieczne, jeśli teksty uczniów mają stać się bardziej indywidualne, niestereotypowe. Należy wziąć pod uwagę także i to, że wzorce adaptacyjne mają charakter twórczy, wymagają kreatywności i bardzo wysokich kompetencji tekstotwórczych, nie są więc dostępne dla wszystkich uczniów. Takich ograniczeń nie mają natomiast wzorce alternacyjne i to one stanowią szansę dla procesu edukacyjnego.

Trawestując tekst piosenki „Śpiewać każdy może / trochę lepiej lub trochę gorzej", można powiedzieć, że w dzisiejszej rzeczywistości kulturowo-komunikacyjnej zdominowanej przez media elektroniczne umożliwiające każdemu chętnemu wypowiadanie się na forum, pisać każdy może. Od odpowiedzialności, by było to raczej pisanie (trochę) lepsze niż (trochę) gorsze, dydaktyka polonistyczna nie może się odżegnać. Refleksja lingwodydaktyczna nad kształceniem kompetencji tekstotwórczej w XXI wieku wydaje się tym samym konieczna.

\section{Bibliografia:}

Bernstein Basil, 1990, Odtwarzanie kultury, Warszawa.

Davies Alan, Widdowson Henry G., 1983, Czytanie i pisanie, w: Kurs edynburski językoznawstwa stosowanego, t. II, Warszawa, s. 132-157.

Duszak Anna, 1998, Tekst, dyskurs, komunikacja międzykulturowa, Warszawa.

Dydaktyka literatury i języka polskiego $w$ gimnazjum $w$ świetle nowej podstawy programowe. Region II. Raport końcowy, 2013, Sopot/Warszawa [tekst niepublikowany].

Dyduchowa Anna, 1988, Metody kształcenia sprawności językowej uczniów: projekt systemu, model podręcznika, Kraków.

Grabias Stanisław, 1994, Język w zachowaniach społecznych, Lublin.

Karwatowska Małgorzata, Wiśniewska Halina, 1998, O typowości tekstów uczniowskich, w: Bartmiński J., Boniecka B. (red.), Tekst. Analizy i interpretacje, Lublin, s. 255-266.

Kłakówna Zofia A., 2016, Język polski. Wykłady z metodyki, Kraków.

Martyniuk Waldemar, 2006, Europejski system opisu kształcenia językowego a nauczanie języka polskiego jako obcego, w: $Z$ zagadnień dydaktyki języka polskiego jako obcego, Lipińska E., Seretny A. (red.), Kraków, s. 117-129.

Nocoń Jolanta, 2002, Transformacje tekstów w edukacji językowej, w: $W$ kręgu zagadnień dydaktyki języka i literatury polskiej, Synowiec H. (red.), Katowice, s. 171-177. 
Nocoń Jolanta, 2018, Lingwodydaktyka na progu XXI wieku. Konteksty - koncepcje - dylematy, Opole.

Nocoń Jolanta, 2018a, Wariantywność stylu tekstu w perspektywie edukacyjnej, „Stylistyka” XXVII.

Nocoń Jolanta, 2020, Kształcenie umiejętności pisania w języku ojczystym $w$ perspektywie lingwistycznej i lingwodydaktycznej, „Didaktické Studie”, nr 1.

Skudrzyk Aldona, 2005, Czy zmierzch kultury pisma? O synestezji i analfabetyzmie funkcjonalnym, Katowice.

Warchala Jacek, Skudrzyk Aldona, 2010, Kultura piśmienności młodego pokolenia, Katowice.

Wierzbicka Anna, Wierzbicki Piotr, 1970, Praktyczna stylistyka, Warszawa.

Wiśniewska Halina, 2002, Bogactwo/ubóstwo słownika jako przejaw stereotypowego myślenia o sprawności językowej uczniów, w: W kręgu zagadnień dydaktyki języka i literatury polskiej, Synowiec H. (red.), Katowice, s. 132-141.

Wiśniewska Halina, 2016, Schematyzm działań dydaktycznych przyczyna niskiej sprawności pragmatycznej (na przykładzie opisów szkolnych), w: Wokół edukacji polonistycznej w szkole. Teoria i praktyka, Karwatowska M., Tymiakin L. (oprac. i red.), Lublin, s. 279-289.

Witosz Bożena, 2005, Genologia lingwistyczna. Zarys problematyki, Katowice.

Wojtak Maria, 2004, Gatunki prasowe, Lublin.

\section{O Autorce:}

Jolanta Nocoń - prof. dr hab.; pracuje na Uniwersytecie Opolskim w Instytucie Językoznawstwa. Zajmuje się lingwistyką stosowaną oraz stylistyką tekstu i dyskursu, szczególnie problemami edukacji językowej w zakresie języka polskiego jako ojczystego oraz analizą dyskursu edukacyjnego, gatunków i stylu (stylów) tego dyskursu. 